\title{
All The Women Dancing
}

\author{
Mary Cameron
}

\section{Toutes les femmes dansant}

Ce poème en prose tente de faire apparaitre "l'essentiel" en chacun, chacune: la musique que l'on porte en soi, la façon dont notre corps bouge... Dans ces échanges sans paroles, une demande extravagante: "l'amour." Le réel (où ce que nous prenons pour tel: le bar, les rues) nous coupe, nous met en éclats (le verre brisé) parce qu'il danse au rythme de la violence.

Don't give me that.

push past the cracked pane of glass and walk right up to the bar. don't hesitate to squeeze between bar stools, keep pressing til you have smooth wood under your hands, a cocktail napkin between your fingers. there'll be voices coming at you - a woman will tug at your sleeve, a man will bellow in your ear. don't get pushed back. this is a bar. listen.

He was seventeen and the dimple was lopsided. Not up and down-you know, Paul Newman? - on an angle. Left to right, right to left, 
I don't remember. Pass me your lighter.

Anyway, I said to him, "Forget it

baby. You can't come in here again."

listen. because you can't

see anything

except the high glass

and carved wood of the bar,

liquor bottles lined up

like a mystery.

what will the gin say.

what will come in the

course of the evening.

and you remember a woman once fell

off her bicycle as she was

riding by. she said she was listening

to the music. the bicycle wheel

revolved, slowly ticking.

a line of cloud across the moon.

then a guy smashed his hand

on the glass paned door

when she wouldn't dance.

And she said

to me, "That's what I think

of you. That's what I think."

the music comes from the

speakers, just guitar

and drums, no voice.

a long legged man

extends the mike stands

in the back corner, spot lit.

She'll take my money, split it, like loaves, right? Split it hundreds of ways between the kids and her and her mom. Nothing's coming back to me, that's for sure.

Don't kid yourself. They do it 
for money. They always get what they want.

and down the street the flashing

neon nipples above the sidewalk, men against store windows. an open door with red velvet walls dim inside, a sparkly lined showcase of photos. car horns in the street and the women in dressing rooms, waiting to strip, waiting to eat. the flip of a hand toward an ashtray, glass falling in shards on a stage, their skin dancing, eyes on the wall.

I don't think about it, usually. I'd get too upset.

the singer steps out of the men's room wearing a powder blue suit with torn lapels. his shirt strains over his belly, and a wispy pointed red beard draws his mouth down to a sneer. he squints in the light. Guitar. swings the strap over his head and settles the guitar across his chest. O.K. folks, start your drinking doubles and feeling single. Boys, lets talk.

and he flashes his hand down to the guitar and rolls across a chord with the pitch of the drums behind, then leans into the sound 
with the long legged man

on the bass beside him.

his mouth twists

words across the dance floor.

Baby don't you go.

the bass line rises

through your shoes and that guitar

cuts a line, it seems, from ear

to ear. all the women dancing

lift their heads, listen

to their bodies move.

listen. the sound is in

your head, it's in your glass

as you raise it and drain

the last of the gin.

it's in the rocking of bodies

on either side of you. she pushes

you, he pulls you back. this press

to the bar, gin flushing you -

you're hearing hurt, the

pain of leaving, being

left. his words and the crowd's

silent keening, twisting

by the wall. a man pulls

your hand, grabs your ass,

demands you dance with him.

his mouth splits when you

refuse, spits Queer and your

fury rises, glass smashes

on the wooden bar

and the guitar sound leaps

to the ceiling.

all the women dancing, listen.

Baby, don't you go, 'cause

I love you so. and a few

men stop and listen too. 